\title{
A Weather-Type Classification and Its Application to Near-Surface Wind Climate Change Projections over the Adriatic Region
}

\author{
Andreina Belušić Vozila ${ }^{1, * \mathbb{D}}$, Maja Telišman Prtenjak ${ }^{2}$ and Ivan Güttler ${ }^{3}$ \\ 1 Institute of Agriculture and Tourism, 52440 Poreč, Croatia \\ 2 Department of Geophysics, Faculty of Science, University of Zagreb, 10000 Zagreb, Croatia; telisman@gfz.hr \\ 3 Croatian Meteorological and Hydrological Service, 10000 Zagreb, Croatia; ivan.guettler@cirus.dhz.hr \\ * Correspondence: abelusic@gfz.hr
}

Citation: Belušić Vozila, A.; Telišman Prtenjak, M.; Güttler, I. A

Weather-Type Classification and Its Application to Near-Surface Wind Climate Change Projections over the Adriatic Region. Atmosphere 2021, 12, 948. https://doi.org/10.3390/ atmos12080948

Academic Editor: Qiusheng Li

Received: 29 June 2021

Accepted: 19 July 2021

Published: 23 July 2021

Publisher's Note: MDPI stays neutral with regard to jurisdictional claims in published maps and institutional affiliations.

Copyright: () 2021 by the authors. Licensee MDPI, Basel, Switzerland. This article is an open access article distributed under the terms and conditions of the Creative Commons Attribution (CC BY) license (https:// creativecommons.org/licenses/by/ $4.0 /)$.

\begin{abstract}
The main goal of this study is to present a recently developed classification method for weather types based on the vorticity and the location of the synoptic centers relative to the Adriatic region. The basis of the present objective classification, applied to the Adriatic region, is the subjective classification developed by Poje. Our algorithm considered daily mean sea-level pressure and $500 \mathrm{hPa}$ geopotential height to define one out of 17 possible weather types. We applied the algorithm to identify which weather type was relevant in the generation of the two typical near-surface winds over the Adriatic region, namely Bora and Sirocco. Two high-resolution $\left(0.11^{\circ}\right)$ EURO-CORDEX regional climate models were used, SMHI-RCA4 and DHMZ-RegCM4, forced by several CMIP5 global climate models and analyzed for two 30-year periods: near-present day and mid-21st century climate conditions under the high-end Representative Concentration Pathway (RCP8.5) scenario. Bora and Sirocco days were extracted for each weather type and a distribution over the 30-year period was presented. Our results suggest that in the winter season, climate model projections indicate a reduction in the main cyclonic types relevant in the formation of Bora over the entire Adriatic region and an increase in the number of anticyclonic types relevant in Sirocco events. In contrast, for the summer season, an increase in the main anticyclonic Bora-related weather types is found in the ensemble over the northern Adriatic region.
\end{abstract}

Keywords: Adriatic region; Bora; climate change; CORDEX; Sirocco; weather-type classification

\section{Introduction}

Weather-type (WT) classification has been an active research topic since the 1950s [1,2]. There are more than a few WT classification algorithms and approaches used in synoptic climatology studies [3,4]. A comprehensive overview of different methodological approaches for circulation type classification and their application in different fields of research is provided by Huth [5]. Classification methods are generally divided into two groups: manual and automatic, or subjective and objective classifications [4]. Subjective methods [1] are based on the forecaster's or researcher's experience, while objective methods can be based on correlation [6], principal component analysis [7], or climate indices [8]. Each of these approaches has its pros and cons, and it is important to note that automatic methods, which are usually considered objective, inevitably have some subjective expert judgments, too.

The first and currently used method for Croatia was developed by Poje [1]. He proposed 29 WTs that constitute a subjective method using pressure information from near-surface and upper synoptic charts. Since two vertical levels (mean sea-level pressure (MSLP) and $500 \mathrm{hPa}$ ) are easily available from regional climate models (RCMs) from the EURO-CORDEX initiative [9], the method proposed by Poje [1] could be further improved and automated. In addition to Poje [1], Bissolli and Dittmann [10] also developed (and tested over Germany) an objective WT classification based on the model outputs of 
several meteorological variables that use multiple nested domains. By using the synoptic pressure and wind characteristics defined by the former, and the method of domain definition over the area of interest and algorithm calculations defined by the latter, a new semi-objective method was developed. Very recently, this classification was successfully tested by Jelić et al. [11,12] for hail investigation using ERA5 input data. The authors showed that the algorithm succeeded in realistically capturing the WTs responsible for hail events over the northeastern Adriatic.

We aimed to find a robust relation between the large-scale parameter, MSLP, and a parameter dependent on the small-scale influence, the near-surface wind field, over the Adriatic region. Other studies analyzed this relationship in other areas of Europe and revealed that RCMs preserve almost all large-scale features emerging from global climate models (GCMs) that provide initial (ICs) and boundary conditions (BCs) $[13,14]$. At the same time, GCMs affect the small-scale climate signal that mainly arises from RCMs [15-17]. GCM projections show that the main baric centers over Europe (Iceland low and Azores high) could shift northeastward [18,19], leading to the intensification of the pressure gradient over Europe [19,20]. In addition, McCabe et al. [21] showed a significant reduction in cyclonic activities in northern middle latitudes in the last 40 years, while Catto et al. [22] found a projected decrease in the northern mid-latitude cyclones in both DJF (December-January-February) and JJA (June-July-August) using the Coupled Model Intercomparison Project Phase 5 (CMIP5) simulations. There is also an indication that by the end of the 21st century, the anticyclonic influence may increase at the expense of the decrease in cyclonic circulations over the Mediterranean region $[13,17,18]$, especially in the winter season. Furthermore, cyclone paths over the southern Mediterranean could also be reduced [23]. Previous studies have likewise found a link between the decrease in the number of cyclones over the Mediterranean and the decrease in wind speed [24,25].

Despite analyses of other parts of Europe, or of Europe as a whole, studies investigating the observed and projected changes in (anti)cyclonic activities compared to Bora and Sirocco winds are still rare. Bora and Sirocco belong to the dominant (regional) winds, mostly from the NE-E and SE-S directions over the Adriatic, respectively [26,27]. The Bora is a gusty off-shore wind that brings drier and colder air over the coastal region, while Sirocco is a warmer, more humid wind usually associated with convection. Both types of airflow often reach severe speeds. Pandžić and Likso [26] showed that Bora, in winter, usually starts as a cyclonic type in the northern part of the Adriatic; afterwards, it expands along the Adriatic as an anticyclonic type. Bora, during summer, is mostly anticyclonic and weak. On the other hand, Sirocco is mostly cyclonic in both winter and summer seasons [26].

Additionally, we previously examined the climatology of Bora and Sirocco over the Adriatic [27] and found how the wind regimes change with changing climate [28]. Belušić et al. [27] revealed that despite the complex topography and steep terrain slopes along the Adriatic, selected RCMs are able to reliably represent Bora and Sirocco winds. Furthermore, Belušić Vozila et al. [28] showed that there is an indication of a reduction in the number of Bora events during the winter season, accompanied by a higher wind speed in the northern Adriatic. Sirocco is likely to be more frequent in the middle Adriatic, but with a lower mean wind speed. Summer-season Bora will be enhanced in a number of events, especially within the well-known Bora jets [29]. Our intention here is to complement the work of Belušić Vozila et al. [28], and to explain these projected changes in Bora and Sirocco over the Adriatic region using a recently developed WT classification.

\section{Climate Model Data}

Two high-resolution $\left(0.11^{\circ}\right)$ EURO-CORDEX models, SMHI-RCA4 (developed at the Swedish Meteorological and Hydrological Institute [30]) and DHMZ-RegCM4 (implemented at the Croatian Meteorological and Hydrological Service [31]), were examined. Five different CMIP5 GCMs provided BCs for the RCA4 model, while four CMIP5 GCMs provided BCs for RegCM4, as seen in Table 1. The multi-model ensemble therefore consists 
of nine simulations. A high-end greenhouse gas scenario assuming a radiative forcing of $8.5 \mathrm{~W} / \mathrm{m}^{2}$ at the end of the century (RCP8.5) [32] was considered for all available simulations. Climate change was investigated using two 30-year periods: near present-day (P0: 1971-2000) and future climate conditions (P2: 2041-2070). Daily data for wind, MSLP, and geopotential at $500 \mathrm{hPa}$ level were extracted from all nine mentioned simulations for the DJF and JJA seasons.

Table 1. Overview of the analyzed simulations.

\begin{tabular}{|c|c|c|}
\hline Regional Climate Model (RCM) & Institution (Abbreviation) & $\begin{array}{c}\text { Global Climate Model (GCM) as } \\
\text { a Boundary Condition from Coupled Model } \\
\text { Intercomparison Project Phase } 5 \text { (CMIP5) }\end{array}$ \\
\hline RCA4 [30] & $\begin{array}{c}\text { Swedish Meteorological and Hydrological } \\
\text { Institute } \\
\text { (SMHI) }\end{array}$ & $\begin{array}{c}\text { CNRM-CERFACS-CNRM-CM5 [33] } \\
\text { ICHEC-EC-EARTH [34] } \\
\text { IPSL-IPSL-CM5A-MR1 [35] } \\
\text { MOHC-HadGEM2-ES [36] } \\
\text { MPI-M-MPI-ESM-LR [37] }\end{array}$ \\
\hline RegCM4 [31] & $\begin{array}{l}\text { Croatian Meteorological and Hydrological } \\
\text { Service } \\
\text { (DHMZ) }\end{array}$ & $\begin{array}{c}\text { CNRM-CERFACS-CNRM-CM5 } \\
\text { ICHEC-EC-EARTH } \\
\text { MOHC-HadGEM2-ES } \\
\text { MPI-M-MPI-ESM-MR }\end{array}$ \\
\hline
\end{tabular}

\section{Method}

\subsection{The Weather-Type Classification Algorithm}

The semi-objective method for defining weather types (17 categories) over the entire domain is introduced here. The algorithm uses MSLP data and $500 \mathrm{hPa}$ geopotential height data to identify the corresponding WT for each day over the entire domain. The domain covers the $5^{\circ}-21^{\circ} \mathrm{E}$ and the $35^{\circ}-50^{\circ} \mathrm{N}$ area (Figure 1) in order to enclose all the baric systems entering the Adriatic area and affecting the wind field. We nested an inner domain covering $11^{\circ}-20^{\circ} \mathrm{E}$ and $40^{\circ}-48^{\circ} \mathrm{N}$, as illustrated in Figure 1. The inner domain was defined to capture the zonal inflow entering the Adriatic area [38]. All grid points inside the inner domain have doubled weights in the gradient and the Laplacian calculation (in the case of vorticity) as compared to the grid points in the outer frame. Sensitivity tests were performed using various numbers of grid points and different grid configurations. Our tests revealed that the WT classification is affected by domain size and grid configurations. From this, it is clear that the spatial scale needs to be related to the typical scale of synoptic circulation patterns relevant in the area of study.

The first step in the calculation was to find the weighted daily mean within the domain of both pressure Laplacian and the geopotential Laplacian, which provide information on the lower and upper vorticity over the domain. Furthermore, we examined the pressure extrema. If the pressure center (minimum/maximum) over the domain was smaller/larger than $1013.25 \mathrm{hPa}$, and if the MSLP Laplacian was simultaneously positive/negative, the vorticity over the domain was defined as cyclonic/anticyclonic (following [10]). It is important to note that the pressure minimum/maximum is not necessarily in the selected domain (especially maxima). In these cases, we detected the closest isobaric line to the synoptic center affecting the domain.

The objectively derived WTs are composed of 17 different weather patterns, eight of which corresponded to cyclones, another eight to anticyclones, while one pattern represented a quasi-non-gradient field where the mean pressure gradient $\nabla p$ over the domain was less than $0.9 \mathrm{hPa} / 100 \mathrm{~km}$ (following [39], but adjusting for our domain of interest). Since the wind regime over the Adriatic largely changes depending on the sector of the synoptic system that affects the domain, we further divided our domain into four regions, taking into account the position of the synoptic system (Table 2). They are the front sector of the synoptic system affecting the domain (WT containing number 1), the upper sector of the system affecting the domain (WT containing number 2), the back of the system 
affecting the domain (WT containing number 3), and the lower sector of the synoptic system affecting the domain (WT containing number 4). Additionally, for each of the WTs, we differentiated between deep (extending through the troposphere, from the surface to $500 \mathrm{hPa}, \mathrm{CC}$ or AA) and shallow (in the lowermost layer from the surface, mostly below $700 \mathrm{hPa}, \mathrm{CA}$ or AC) systems. Finally, one WT was associated with a particular day in the entire domain of interest. In order to demonstrate the defined WTs, Figures 2 and 3 show the 30-year mean of MSLP for C1-C4 and A1-A4 (regardless of the upper vorticity), and the quasi-non-gradient WTs in the winter (DJF) and summer (JJA) seasons, respectively.

The overall number of cyclonic, anticyclonic, and quasi-non-gradient days in both periods of interest (P0, P2) was addressed first. Afterwards, future changes in the corresponding days were examined. The results are presented as a median of the ensemble of nine RCM simulations.

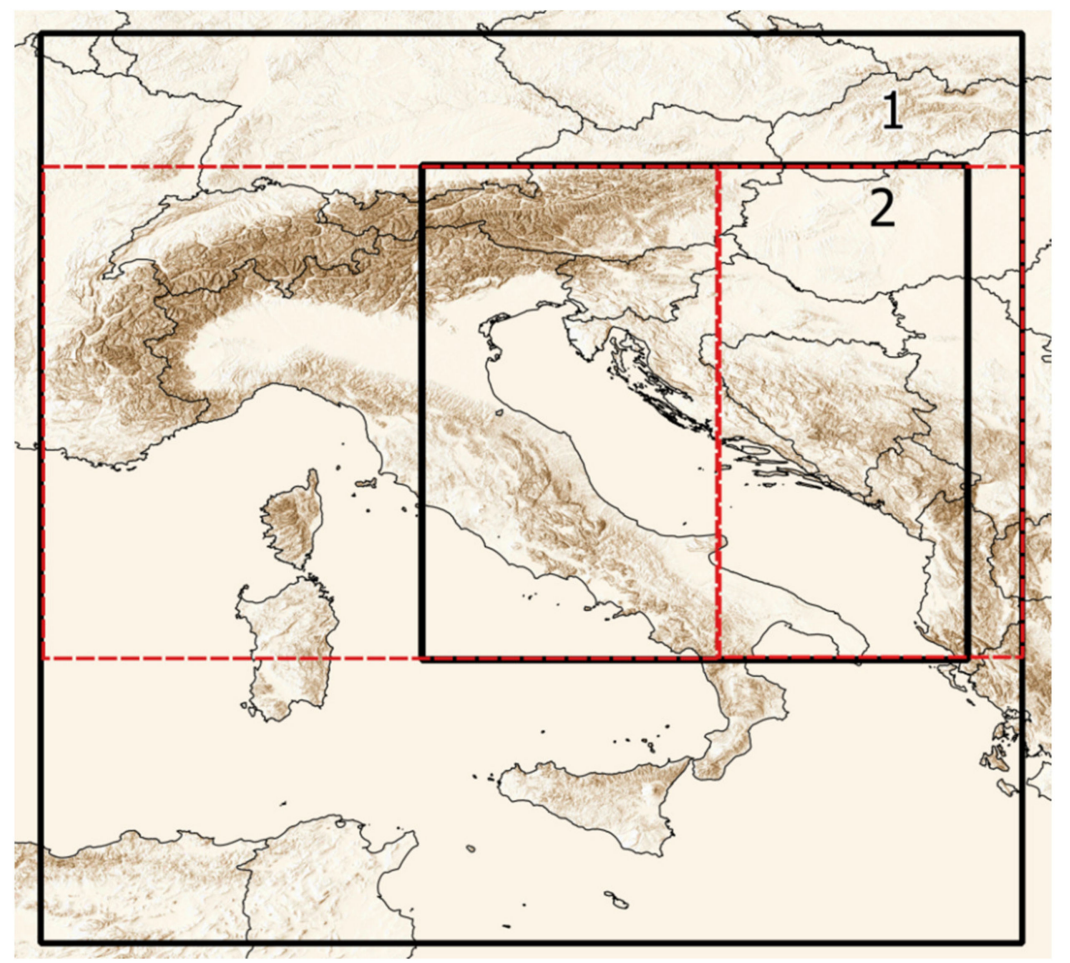

Figure 1. Region of interest with topography in brown. Outer domain (1) and the nested inner domain (2) used in the WT algorithm for WT computation in solid black. The horizontal red dashed lines indicate $40^{\circ} \mathrm{N}$ and $48^{\circ} \mathrm{N}$, while the vertical line indicates $16^{\circ} \mathrm{E}$. The red lines divide the outer domain into four regions and are used to associate numbers 1-4 to the corresponding WT, as shown in Table 2.

Table 2. Weather type definition.

\begin{tabular}{ll}
\hline C1C & $\begin{array}{l}\text { Deep cyclone located westward. Cyclone center located between } 40^{\circ} \mathrm{N} \text { and } 48^{\circ} \mathrm{N} \text { and west of } 16^{\circ} \text { E. Cyclonic vorticity } \\
\text { at mean sea-level and at } 500 \mathrm{hPa} \text {. The front of the cyclone affecting the domain. }\end{array}$ \\
\hline $\mathrm{C} 1 \mathrm{~A}$ & $\begin{array}{l}\text { Shallow cyclone located westward. Cyclone center located between } 40^{\circ} \mathrm{N} \text { and } 48^{\circ} \mathrm{N} \text { and west of } 16^{\circ} \text { E. Cyclonic } \\
\text { vorticity at mean sea-level and anticyclonic at } 500 \mathrm{hPa} \text {. The front of the cyclone affecting the domain. }\end{array}$ \\
\hline $\mathrm{C} 2 \mathrm{C}$ & $\begin{array}{l}\text { Deep cyclone located southward. Cyclone center located south of } 40^{\circ} \mathrm{N} \text {. Cyclonic vorticity at mean sea-level and at } \\
500 \mathrm{hPa} \text {. The upper sector of the cyclone affecting the domain. }\end{array}$ \\
\hline $\mathrm{C} 2 \mathrm{~A}$ & $\begin{array}{l}\text { Shallow cyclone located southward. Cyclone center located south of } 40^{\circ} \mathrm{N} \text {. Cyclonic vorticity at mean sea-level and } \\
\text { anticyclonic at } 500 \mathrm{hPa} \text {. The upper sector of the cyclone affecting the domain. }\end{array}$ \\
\hline $\mathrm{C} 3 \mathrm{C}$ & $\begin{array}{l}\text { Deep cyclone located eastward. Cyclone center located between } 40^{\circ} \mathrm{N} \text { and } 48^{\circ} \mathrm{N} \text { and east of } 16^{\circ} \mathrm{E} \text {. Cyclonic vorticity at } \\
\text { mean sea-level and at } 500 \mathrm{hPa} \text {. The back of the cyclone affecting the domain. }\end{array}$ \\
\hline $\mathrm{C} 3 \mathrm{~A}$ & $\begin{array}{l}\text { Shallow cyclone located eastward. Cyclone center located between } 40^{\circ} \mathrm{N} \text { and } 48^{\circ} \mathrm{N} \text { and east of } 16^{\circ} \mathrm{E} \text {. Cyclonic vorticity } \\
\text { at mean sea-level and anticyclonic at } 500 \mathrm{hPa} \text {. The back of the cyclone affecting the domain. }\end{array}$ \\
\hline
\end{tabular}


Table 2. Cont

\begin{tabular}{|c|c|}
\hline $\mathrm{C} 4 \mathrm{C}$ & $\begin{array}{l}\text { Deep cyclone located northward. Cyclone center located north of } 48^{\circ} \mathrm{N} \text {. Cyclonic vorticity at mean sea-level and at } \\
500 \mathrm{hPa} \text {. The lower sector of the cyclone affecting the domain. }\end{array}$ \\
\hline $\mathrm{C} 4 \mathrm{~A}$ & $\begin{array}{l}\text { Shallow cyclone located northward. Cyclone center located north of } 48^{\circ} \mathrm{N} \text {. Cyclonic vorticity at mean sea-level and } \\
\text { anticyclonic at } 500 \mathrm{hPa} \text {. The lower sector of the cyclone affecting the domain. }\end{array}$ \\
\hline A1C & $\begin{array}{l}\text { Shallow anticyclone located westward. Anticyclone center located between } 40^{\circ} \mathrm{N} \text { and } 48^{\circ} \mathrm{N} \text { and west of } 16^{\circ} \mathrm{E} \text {. } \\
\text { Anticyclone center between } 40^{\circ} \mathrm{N} \text { and } 48^{\circ} \mathrm{N} \text { and westward from } 16^{\circ} \mathrm{E} \text {. }\end{array}$ \\
\hline A1A & $\begin{array}{l}\text { Deep anticyclone located westward. Anticyclone center located between } 40^{\circ} \mathrm{N} \text { and } 48^{\circ} \mathrm{N} \text { and west of } 16^{\circ} \mathrm{E} \text {. The front } \\
\text { of the anticyclone affecting the domain. Anticyclonic vorticity at mean sea-level and at } 500 \mathrm{hPa} \text {. The front of } \\
\text { the anticyclone affecting the domain. }\end{array}$ \\
\hline $\mathrm{A} 2 \mathrm{C}$ & $\begin{array}{l}\text { Shallow anticyclone located southward. Anticyclone center located south of } 40^{\circ} \mathrm{N} \text {. Anticyclonic vorticity at mean } \\
\text { sea-level and cyclonic at } 500 \mathrm{hPa} \text {. The upper sector of the anticyclone affecting the domain. }\end{array}$ \\
\hline $\mathrm{A} 2 \mathrm{~A}$ & $\begin{array}{l}\text { Deep anticyclone located southward. Anticyclone center located south of } 40^{\circ} \mathrm{N} \text {. Anticyclonic vorticity at mean sea-level } \\
\text { and at } 500 \mathrm{hPa} \text {. The upper sector of the anticyclone affecting the domain. }\end{array}$ \\
\hline $\mathrm{A} 3 \mathrm{C}$ & $\begin{array}{l}\text { Shallow anticyclone located eastward. Anticyclone center located between } 40^{\circ} \mathrm{N} \text { and } 48^{\circ} \mathrm{N} \text { and east of } 16^{\circ} \mathrm{E} \text {. } \\
\text { Anticyclonic vorticity at mean sea-level and cyclonic at } 500 \mathrm{hPa} \text {. The back of the anticyclone affecting the domain. } \\
\text { Anticyclone is located eastward. }\end{array}$ \\
\hline $\mathrm{A} 3 \mathrm{~A}$ & $\begin{array}{l}\text { Deep anticyclone located eastward. Anticyclone center between } 40^{\circ} \mathrm{N} \text { and } 48^{\circ} \mathrm{N} \text { and east of } 16^{\circ} \mathrm{E} \text {. Anticyclonic } \\
\text { vorticity at mean sea-level and at } 500 \mathrm{hPa} \text {. The back of the anticyclone affecting the domain. }\end{array}$ \\
\hline $\mathrm{A} 4 \mathrm{C}$ & $\begin{array}{l}\text { Shallow anticyclone located northward. Anticyclone center located north of } 48^{\circ} \mathrm{N} \text {. Anticyclonic vorticity at mean } \\
\text { sea-level and cyclonic at } 500 \mathrm{hPa} \text {. The lower sector of the anticyclone affecting the domain. Anticyclone is located } \\
\text { northward. }\end{array}$ \\
\hline $\mathrm{A} 4 \mathrm{~A}$ & $\begin{array}{l}\text { Deep anticyclone located northward. Anticyclone center located north of } 48^{\circ} \mathrm{N} \text {. Anticyclonic vorticity at mean sea-level } \\
\text { and at } 500 \mathrm{hPa} \text {. The lower sector of the anticyclone affecting the domain. }\end{array}$ \\
\hline nG & Quasi-non-gradient field. $\nabla p<0.9 \mathrm{hPa} / 100 \mathrm{~km}$ \\
\hline
\end{tabular}
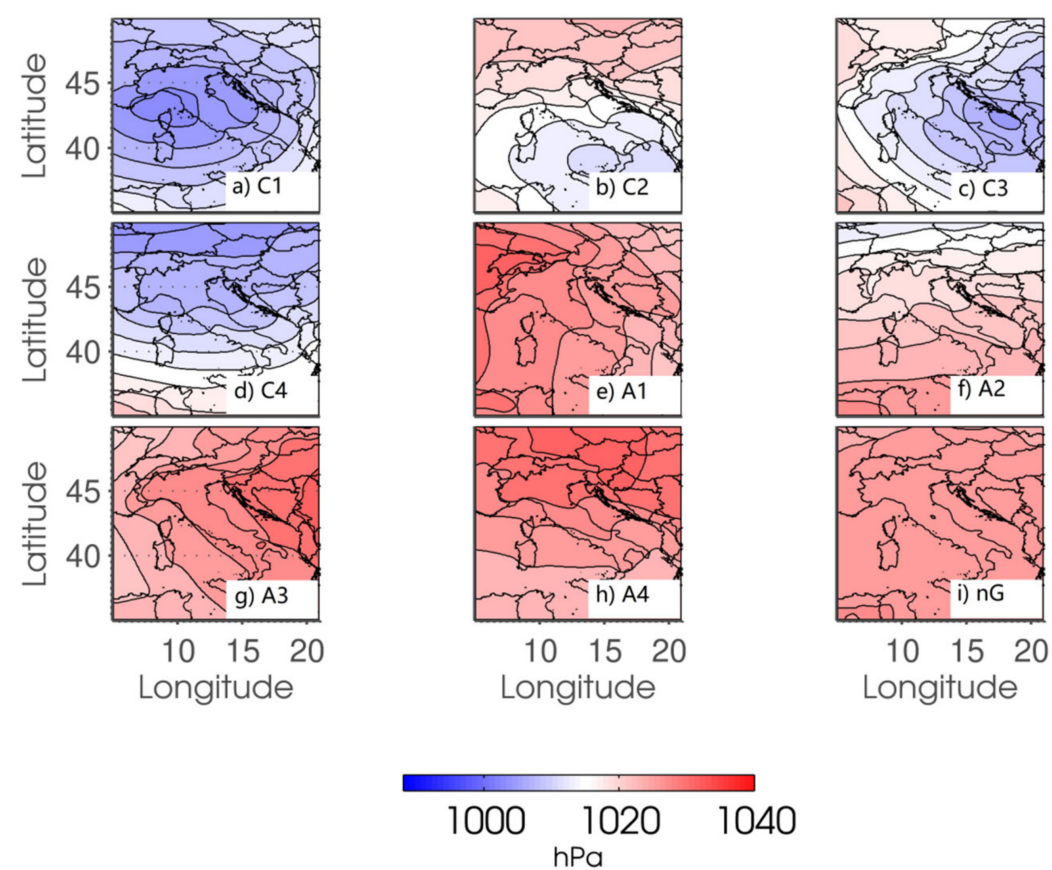

Figure 2. The 30-year mean of MSLP (including both deep and shallow cases) in the near-present period (1971-2000) for the DJF season. The presented example is for the RCA model forced by one of the GCMs (CNRM-CERFACS-CNRM-CM5). (a) Front sector of cyclone (C1), (b) upper sector of cyclone (C2), (c) back sector of cyclone (C3), (d) lower sector of cyclone (C4), (e) front sector of anticyclone (A1), (f) upper sector of anticyclone (A2), (g) back sector of anticyclone (A3), (h) lower sector of anticyclone (A4), (i) quasi-non-gradient field (nG). 

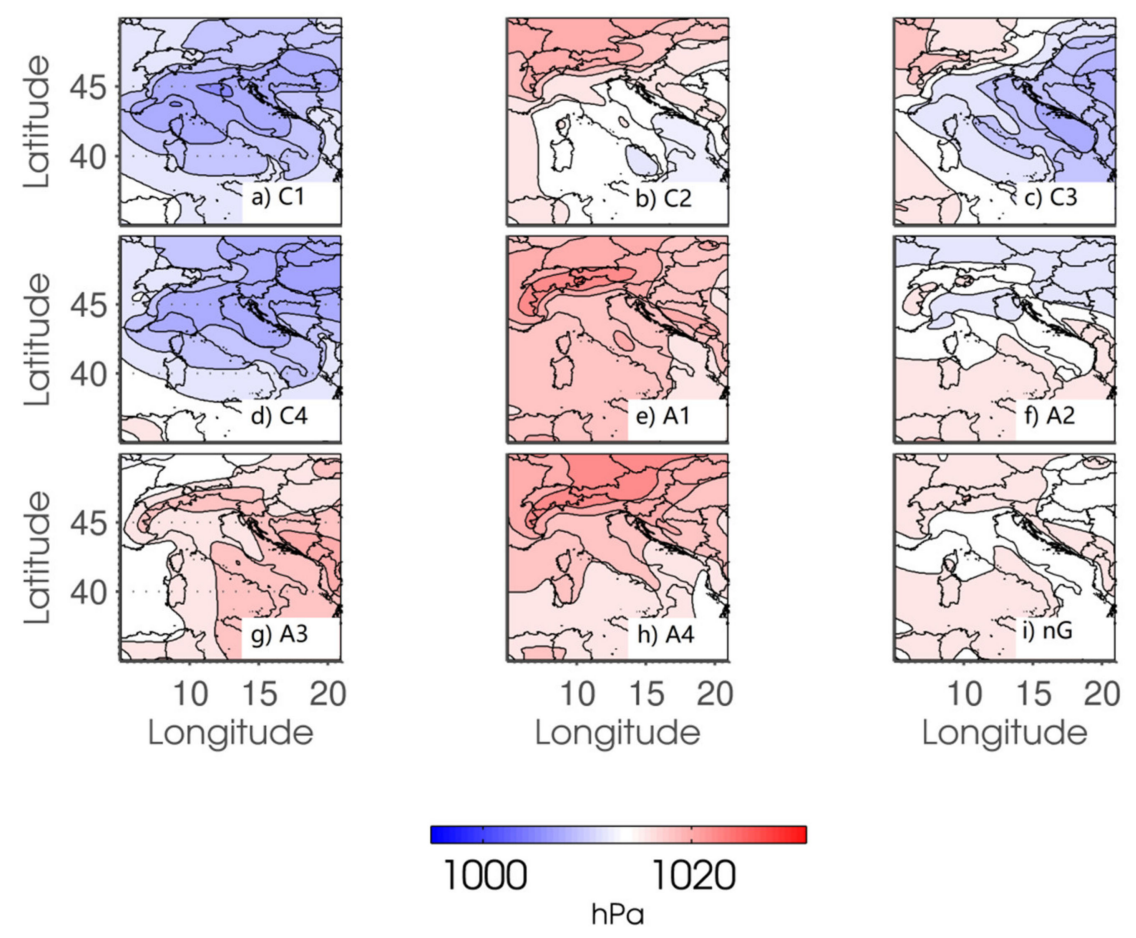

Figure 3. The 30-year mean of MSLP (including both deep and shallow cases) in the near-present period (1971-2000) for the JJA season. The presented example is for the RCA model forced by one of the GCMs (CNRM-CERFACS-CNRM-CM5). (a) Front sector of cyclone (C1), (b) upper sector of cyclone (C2), (c) back sector of cyclone (C3), (d) lower sector of cyclone (C4), (e) front sector of anticyclone (A1), (f) upper sector of anticyclone (A2), (g) back sector of anticyclone (A3), (h) lower sector of anticyclone (A4), (i) quasi-non-gradient field (nG).

\subsection{A Link between WTs and Wind Regimes}

Following Belušić et al. [27] and Belušić Vozila et al. [28], two direction ranges were analyzed in detail for each grid point on the daily scale: NNE $\left(22.5^{\circ}\right)$-ENE $\left(67.5^{\circ}\right)$ and ESE $\left(112.5^{\circ}\right)$-SSE $\left(157.5^{\circ}\right)$, which correspond to Bora and Sirocco directions, respectively. For the definition of Bora and Sirocco, we also determined a daily near-surface wind speed limit of $5 \mathrm{~m} / \mathrm{s}$ for each grid point in order to smooth out various combinations of thermally induced flows (slope winds, sea/land breezes, valley/mountain winds, etc.). The threshold also differentiates thermally formed burin [40] from weak Bora cases in the nighttime hours. It is important to note here that the selected Bora and Sirocco ranges are commonly used [41,42]. Applying a broader/thinner range would, to some extent, modify our results. However, we do not expect conclusions to change since the majority of the Bora and Sirocco events were captured within the current range definition. Sensitivity tests regarding the wind speed limit were also performed. Raising the wind speed limit would extract only the most severe cases, which are scattered (not shown).

Finally, for a particular day and for each grid point over the Adriatic Sea, we extracted those meeting our Bora/Sirocco criteria. Summarizing how many times each grid cell fell within the selected Bora/Sirocco definition in the 30-year period produced the Bora/Sirocco distribution. The WTs of these extracted days were already defined, as described previously; therefore, we have the WT distribution for all Bora/Sirocco days. The results are shown as a median of the ensemble of nine simulations.

\section{Results and Discussion}

\subsection{Changes in Weather Types}

We first address the overall number of cyclones and anticyclones in the near-present day and their changes in the middle of the 21st century over the Adriatic in the respective seasons. Table 3 shows that there is almost the same number of cyclones and anticyclones 
in DJF, while in the JJA season, anticyclones clearly dominate. The number of cyclones and quasi-non-gradient fields in the JJA is comparable. Furthermore, there is more quasi-nongradient flow in the JJA season than in the DJF season. Taking into account future changes in RCP8.5 in the number of (anti)cyclones, simulations mostly agree well on the sign of the changes (fourth and eighth rows in Table 3 ). Therefore, we can confidently say that the number of cyclones decreases in both the DJF and JJA seasons, while the number of anticyclones increases over the Adriatic. This is in agreement with previous studies showing fewer cyclones in winter due to their northward shift [18-20,43]. One can also note the significant decrease in the quasi-non-gradient field in the JJA season, which is replaced by anticyclonic systems. This anticyclonic increase may be due to a growing incidence of a well-developed blocking over Europe [44-46].

Table 3. Ensemble median of number of days (NoD) with cyclonic/anticyclonic/quasi-non-gradient flow in the near-present day (1971-2000; second row DJF, sixth row JJA), and ensemble median of the corresponding differences between future climate conditions (2041-2070, RCP8.5) and nearpresent day (1971-2000; third row DJF, seventh row JJA). Fourth and eighth rows show the 1st (q1) and 3rd (q3) quantile of changes in NoD.

\begin{tabular}{cccc}
\hline & Cyclones & Anticyclones & Quasi-Non-Gradient \\
\hline DJF & & & \\
NoD near-present day (median) & 1030 & 1416 & 257 \\
Changes in NoD (median) & -91 & 63 & 1 \\
Changes in NoD (q1, q3) & $-119,-44$ & 9,111 & $-1,40$ \\
JJA & & & 368 \\
NoD near-present day (median) & 568 & 1723 & -167 \\
Changes in NoD (median) & -55 & 106 & $-247,26$ \\
Changes in NoD (q1, q3) & $-77,16$ & 58,233 & \\
\hline
\end{tabular}

To complement Table 3, the DJF and JJA climatology of our WTs and their future changes (RCP8.5) are presented in Table 4 as ensemble medians. We gathered two WTs regardless of the upper vorticity (i.e., $\mathrm{C} 1 \mathrm{C}+\mathrm{C} 1 \mathrm{~A}$ days as $\mathrm{C} 1$, etc.). It can be seen that the upper (C2) and lower (C4) sectors of the cyclone affect the Adriatic domain most in the near-present day in DJF. In future climate conditions, changes in the number of days for the most cyclonic sectors are negative (except for the front sector, C1). Anticyclones in the near-present DJF season move southward; therefore, it is the upper sector (A2) that affects the domain most of the time. The influence of this sector in the future climate of the DJF season further increases. Changes in other anticyclonic sectors are less pronounced (front (A1) and lower (A4) sectors are increasing, while the back (A3) sector is decreasing). Anticyclones dominate in the JJA season, particularly the upper sector (A2). The influence of the front (A1) sector of anticyclones increases in the middle of the 21st century, while the influence of the lower (A4) and back (A3) sectors decrease. Such a result indicates the strengthening of the anticyclonic influence over the Adriatic domain during the summer period.

Table 4. Ensemble median of NoD with a particular WT in the near-present day (1971-2000, second row DJF, fifth row JJA), and ensemble median of differences in number of days with a particular WT between future climate conditions (2041-2070, RCP8.5) and near-present day (1971-2000; third row DJF, sixth row JJA). WTs are gathered regardless of the upper vorticity.

\begin{tabular}{cccccccccc}
\hline & C1 & C2 & C3 & C4 & A1 & A2 & A3 & A4 & nG \\
\hline DJF & & & & & & & & & \\
NoD in 1971-2000 & 180 & 277 & 11 & 467 & 163 & 814 & 95 & 201 & 257 \\
Changes in NoD & 2 & -17 & -12 & -39 & 12 & 55 & -5 & -8 & 1 \\
JJA & & & & & & & & & \\
NoD in 1971-2000 & 77 & 239 & 122 & 121 & 1061 & 293 & 66 & 306 & 369 \\
Changes in NoD & -12 & 22 & -10 & -31 & 221 & -53 & 3 & -20 & -167 \\
\hline
\end{tabular}




\subsection{Weather Types Generating Bora and Sirocco}

From the 17 WTs that we have suggested, the ones that are the most responsible for Bora formation in DJF (Figure 4) are: C2C (along the Adriatic), A4C (along the Adriatic), $\mathrm{C} 3 \mathrm{C}$ (in the northern Adriatic), A4A (along the Adriatic), and C1C (in the northern Adriatic). Only a few Bora days in DJF are generated by: A1C (along the Adriatic), A1A (along the Adriatic), A2A (along the southern Adriatic jet), A3A (along the southern Adriatic jet), and the quasi-non-gradient field (only in the southern Bora jet). On the other hand, JJA Bora (Figure 5) is generated by: $\mathrm{C} 2 \mathrm{C}$ (in the northern Adriatic), A1A (along the Adriatic), $\mathrm{A} 4 \mathrm{C}$ (in the northern Adriatic), $\mathrm{A} 1 \mathrm{C}$ (in the northern Adriatic), and C3C (in the northern Adriatic). Only a few Bora days in JJA are generated by: C1C (in the northern Adriatic), A4A (in the northern Adriatic), and the quasi-non-gradient fields (only in the northern Bora jet). Others have no influence on Bora generation, which is as expected [47]. The quasinon-gradient northeasterly flow is a leftover of the sea-land breeze, triggered by thermal differences between the sea and the land [48].
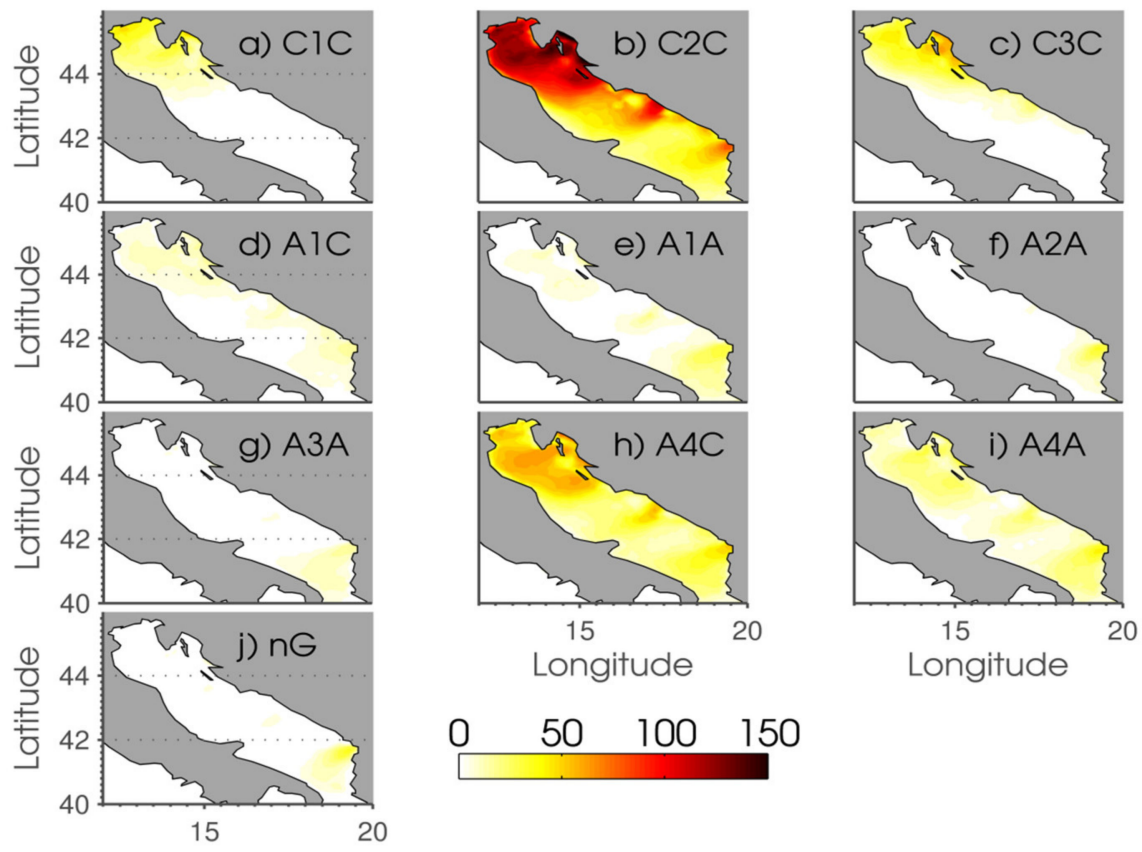

Longitude

Longitude

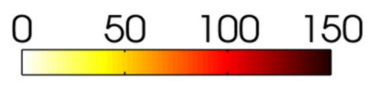$$
20
$$

Figure 4. WT responsible for Bora formation in the near-present day (1971-2000) in DJF; (a) front sector of deep cyclone (C1C), (b) upper sector of deep cyclone (C2C), (c) back sector of deep cyclone (C3C), (d) front sector of shallow anticyclone (A1C), (e) front sector of deep anticyclone (A1A), (f) upper sector of deep anticyclone (A2A), (g) back sector of deep anticyclone (A3A), (h) lower sector of shallow anticyclone (A4C), (i) lower sector of deep anticyclone (A4A), (j) quasi-non-gradient field (nG). 

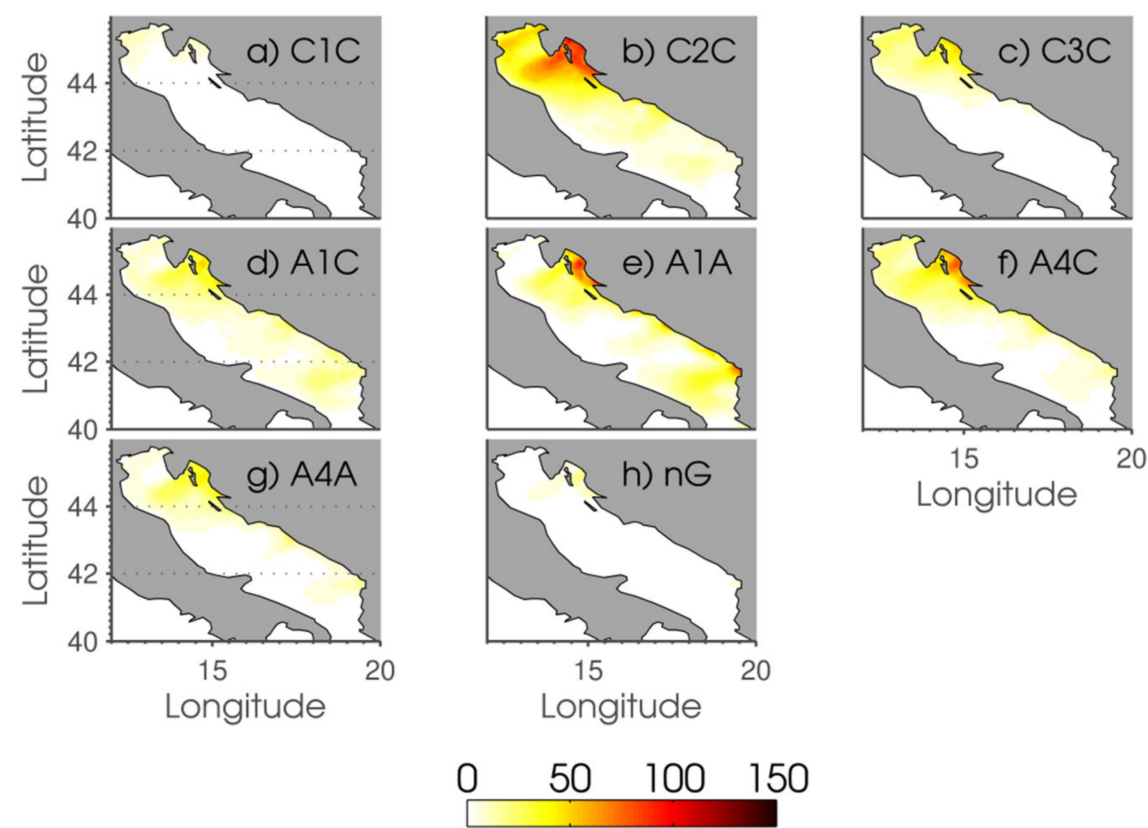

Figure 5. WT responsible for Bora formation in the near-present day (1971-2000) in JJA; (a) front sector of deep cyclone (C1C), (b) upper sector of deep cyclone (C2C), (c) back sector of deep cyclone (C3C), (d) front sector of shallow anticyclone (A1C), (e) front sector of deep anticyclone (A1A), (f) lower sector of shallow anticyclone (A4C), (g) lower sector of deep anticyclone (A4A), (h) quasinon-gradient field (nG).

The WTs responsible for Sirocco formation in both DJF (Figure 6) and JJA (Figure 7) are: $\mathrm{A} 2 \mathrm{~A}$ (along the Adriatic), $\mathrm{C} 2 \mathrm{C}$ (along the Adriatic), and $\mathrm{C} 1 \mathrm{C}$ (along the Adriatic). Others have a negligible influence on Sirocco generation, which is expected [49]. Although it is surprising that A2A could generate the Sirocco wind, Sirocco under the influence of this WT has been documented; it brings dry air from the warm southeast sector [50,51]. Pressure maxima during the A2A Sirocco are located south of the Ionian and Mediterranean Sea or over the southern Balkan Peninsula. We inspected particular cases and saw that isobars sometimes distort over the southern Adriatic during A2A (see Figures 2 and 3), making a possibility for Sirocco to generate. This could be due to the topography and large temperature difference between the land and the sea affecting the wind-stress curl and contributing to alongshore wind [52].

Some WTs generate both Bora and Sirocco simultaneously in different parts of the Adriatic. The front sector $(\mathrm{C} 1)$ of the cyclone in the DJF season generates Bora in the north, whereas Sirocco is generated along the coast of the middle and south Adriatic. The upper sector $(\mathrm{C} 2)$ of the cyclone in DJF generates Bora along the Adriatic and Sirocco in the most southern part. This is not surprising and is often documented in the cold season during the cyclonic activity over the Adriatic [53]. Bora wind over the northern Adriatic is accompanied by strong Sirocco wind over the southern Adriatic [50]. C2C cyclones, during which the majority of Bora and Sirocco are generated, are usually deep Genoa cyclones with trajectories over the middle and south Adriatic [46] or cyclones from the western Mediterranean Sea. C1C and C3C are deep Genoa cyclones or Genoa cyclones that triggered the formation of the Adriatic (meso-) cyclone [47]. 

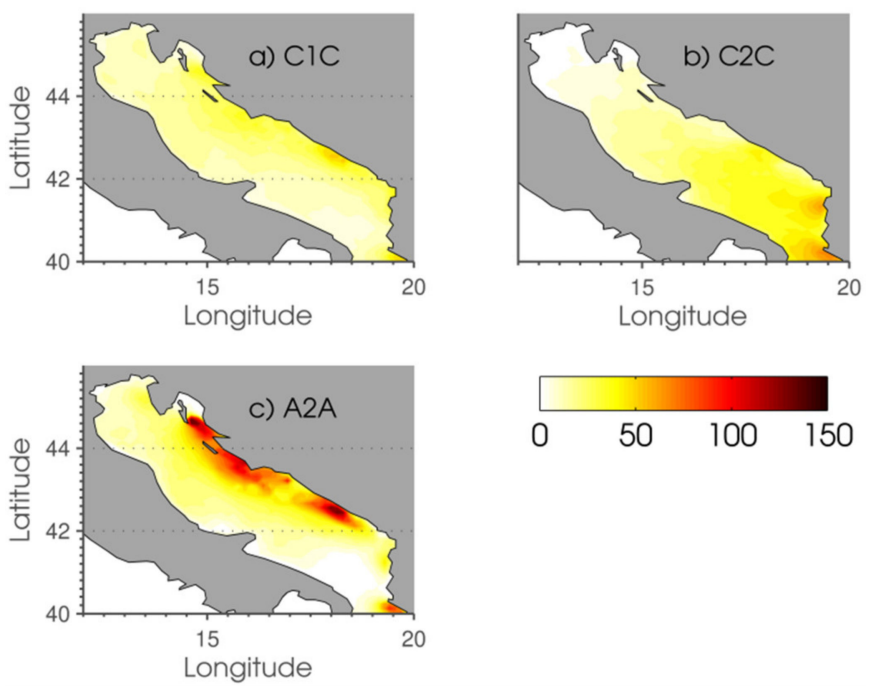

Figure 6. WT responsible for Sirocco formation in the near-present day (1971-2000) in DJF; (a) front sector of deep cyclone (C1C), (b) upper sector of deep cyclone (C2C), (c) upper sector of deep anticyclone (A2A).
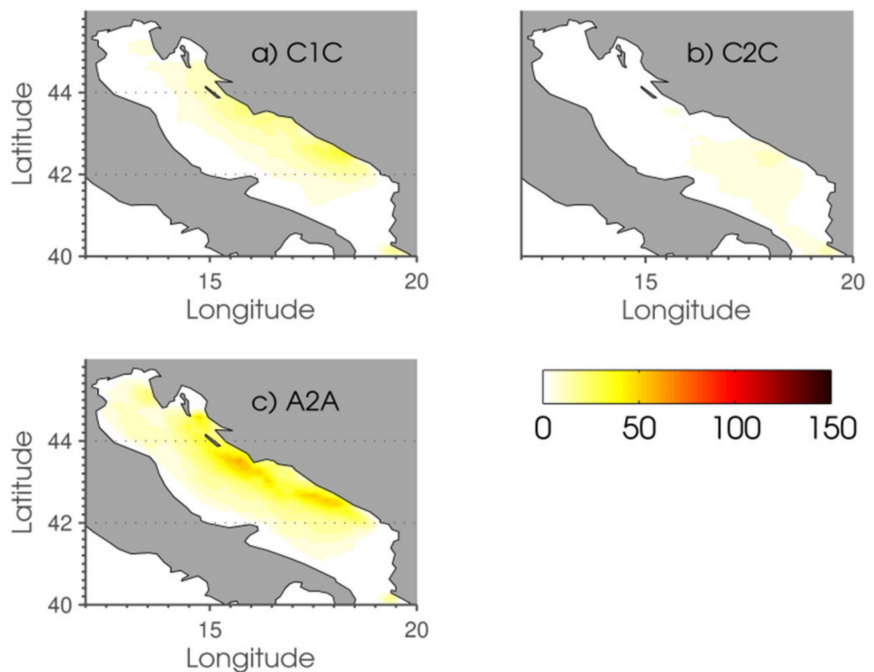

Figure 7. WT responsible for Sirocco formation in the near-present day (1971-2000) in JJA; (a) front sector of deep cyclone (C1C), (b) upper sector of deep cyclone (C2C), (c) upper sector of deep anticyclone (A2A).

\subsection{Explaining Future Changes in Bora and Sirocco Using the WT Approach}

Climate change for WTs generating Bora in DJF (Figure 8) disclose an overall decrease in Bora days generated by the front sector of the cyclone (C1C), upper sector of the cyclone $(\mathrm{C} 2 \mathrm{C})$, back sector of the cyclone (C3C), and lower sector of anticyclones (A4A and A4C). Anticyclonic Bora days are enhanced due to the front sector of anticyclones (A1A). It seems that the anticyclonic influence will become more pronounced in the middle of the 21st century; therefore, A4 synoptic daily situations will be replaced by A1 synoptic daily situations. Altogether, the number of Bora days in DJF is reduced, as described by Belušić Vozila et al. [28]. Unfortunately, these results could not explain the larger wind speed found for the northern Adriatic by Belušić Vozila et al. [28]. For that purpose, we examined the intensities of future cyclones affecting the northern Adriatic. We have found that the pressure minima generating Bora in the northern Adriatic do not substantially change $( \pm 2 \mathrm{hPa})$ in the middle of the 21st century and therefore could not be the reason for a larger mean wind speed in the northern Adriatic. The reason behind those changes 
is out of the scope of this work since we do not account for mesoscale processes within cyclones that can further change the wind field. Furthermore, cyclone center intensity and Bora cannot be straightforwardly correlated [53], and Bora intensity cannot be directly associated with the cyclone depth either. Horvath and Ivančan-Picek [53] also found that the actual values of Bora wind speed are a result of the changes in the synoptic scale (easily detectable by RCMs) and the sub-synoptic processes near the cyclone center (e.g., strong convection, inversion layer, thermal properties, which are much more difficult to see within the EURO-CORDEX simulations). Due to the elective grid step ( $4 \mathrm{dx}$ ), smaller mesoscale processes (here referring to those smaller than $40 \mathrm{~km}$ ) are not well represented or modeled in RMCs. Although the question of the influence of these processes of different scales on the final modeled wind speed remains open, reducing the grid step to approximately $2 \mathrm{~km}$ has shown that wind speeds can be distinguished much better due to the consideration of a number of factors, even in very complex terrain [27].
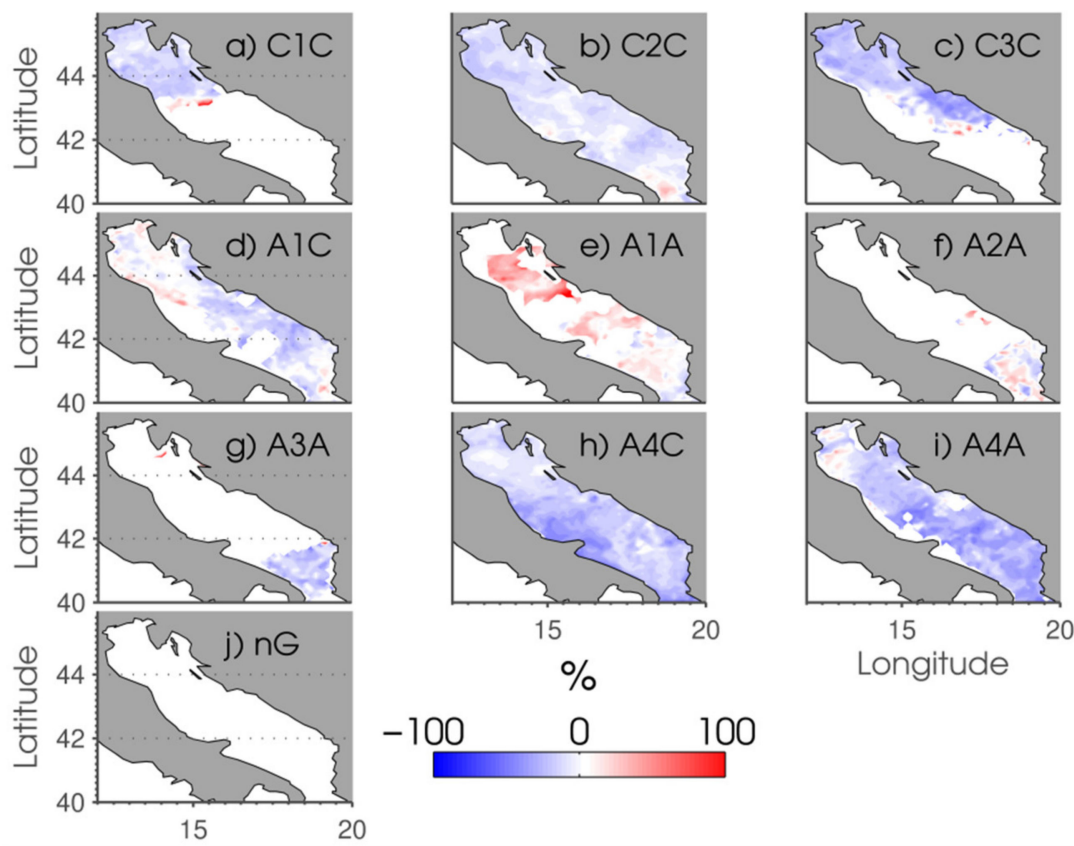

Figure 8. Differences (in \%) in number of Bora days between future climate conditions (2041-2070, RCP8.5) and near-present day (1971-2000), normalized by the number of Bora days in the near-present day in DJF; (a) front sector of deep cyclone (C1C), (b) upper sector of deep cyclone (C2C), (c) back sector of deep cyclone (C3C), (d) front sector of shallow anticyclone (A1C), (e) front sector of deep anticyclone (A1A), (f) upper sector of deep anticyclone (A2A), (g) back sector of deep anticyclone (A3A), (h) lower sector of shallow anticyclone (A4C), (i) lower sector of deep anticyclone (A4A), (j) quasi-non-gradient field (nG).

Summer (JJA) Bora days are overall enhanced in the north (Figure 9, and as found in [28]). This increase within the jets is due to the influence of the front sector of the anticyclones (A1C and A1A) and the upper sector of deep cyclones (C2C). Cyclonic Bora days also decrease in JJA due to the decrease in the back sector (C3) of cyclones. It is interesting to note that quasi-non-gradient Bora days decrease in the north within the well-known Bora jet. Overall, this is a confirmation that quasi-non-gradient WTs will be replaced by anticyclones. 

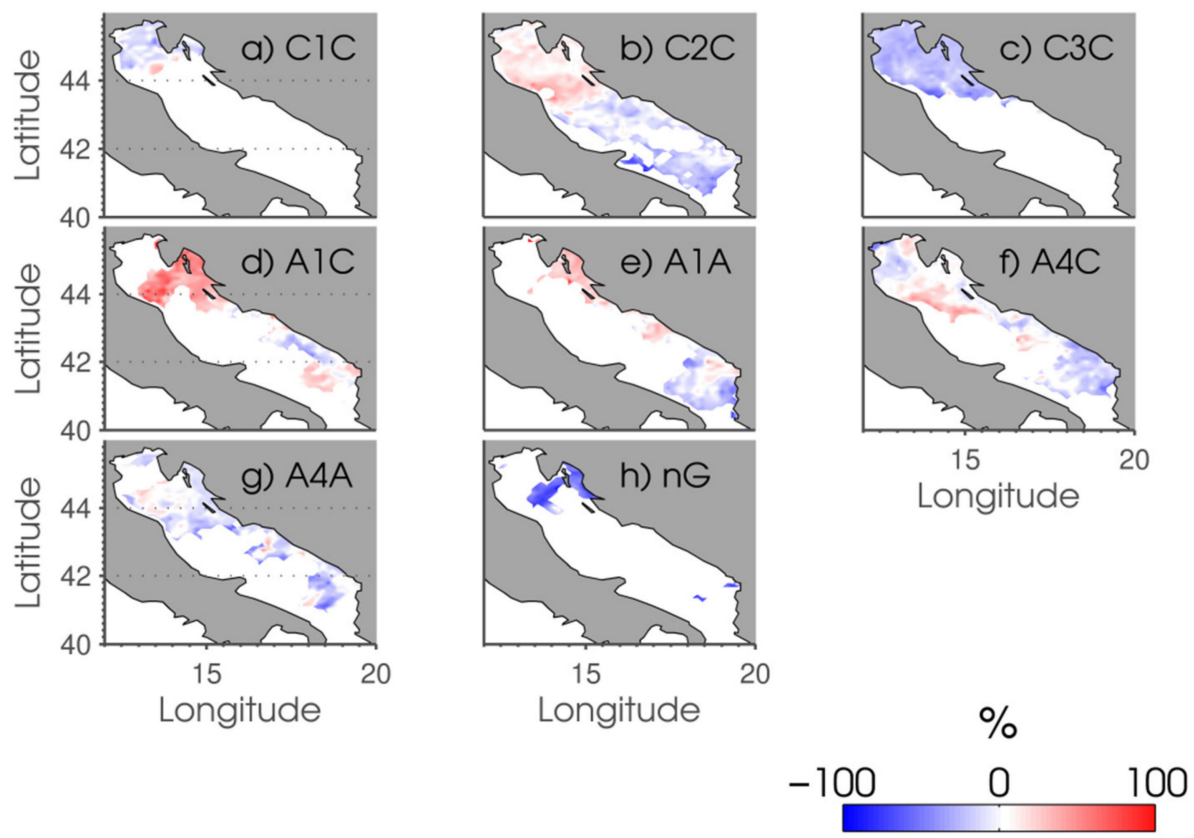

Figure 9. The same as Figure 8, but for JJA; (a) front sector of deep cyclone (C1C), (b) upper sector of deep cyclone (C2C), (c) back sector of deep cyclone (C3C), (d) front sector of shallow anticyclone (A1C), (e) front sector of deep anticyclone (A1A), (f) lower sector of shallow anticyclone (A4C), (g) lower sector of deep anticyclone (A4A), (h) quasi-non-gradient field (nG).

Climate projections regarding Sirocco days in DJF (Figure 10) show an increase (as described by Belušić Vozila et al. [28]) due to the upper sector of the anticyclone (A2A) and due to the front sector of the cyclone (C1C), which support Sirocco generation along the whole Adriatic. Since the strongest Sirocco is generated by cyclones, which are replaced by anticyclonic Sirocco days, the decrease in the mean wind speed found in Belušić Vozila et al. [28] could be explained. The small number of Sirocco days in summer (JJA, Figure 11) further decreases due to the large decrease in all WTs of interest.
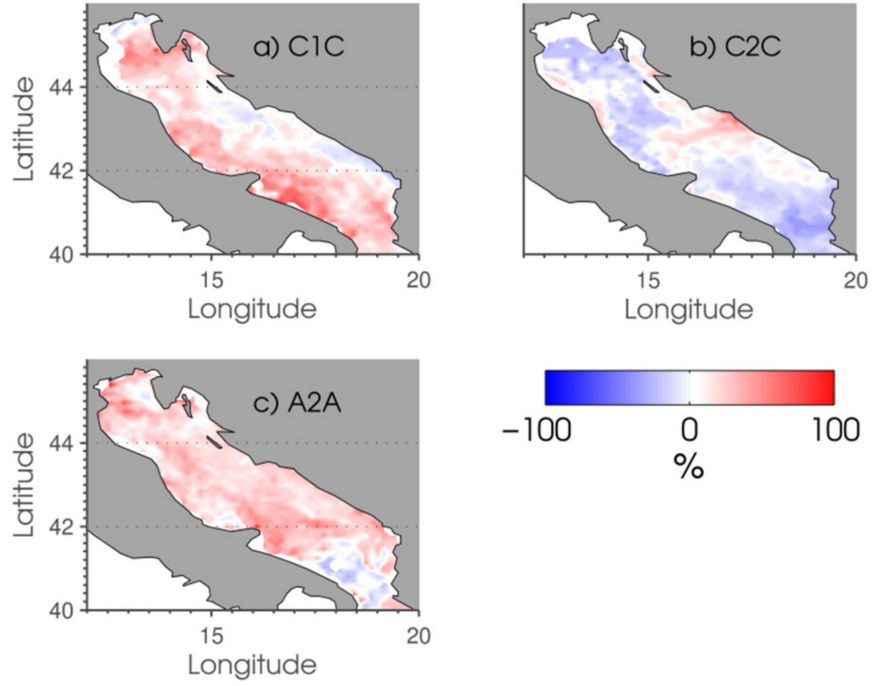

Figure 10. Differences (in \%) in number of Sirocco days between future climate conditions (2041-2070, RCP8.5) and near-present day (1971-2000), normalized by the number of Sirocco days in the nearpresent day in DJF; (a) front sector of deep cyclone (C1C), (b) upper sector of deep cyclone (C2C), (c) upper sector of deep anticyclone (A2A). 

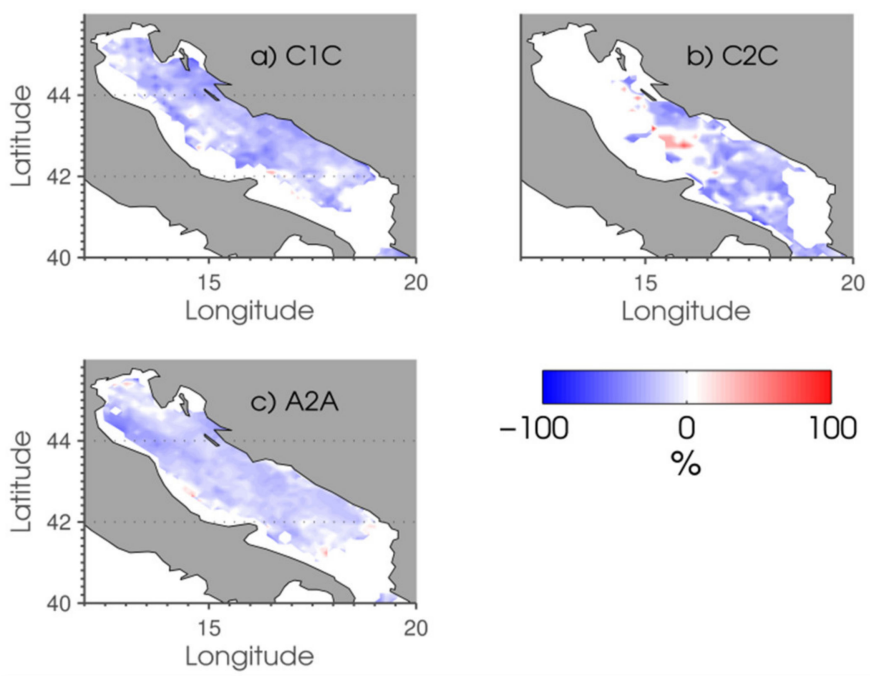

Figure 11. The same as Figure 10, but for JJA; (a) front sector of deep cyclone (C1C), (b) upper sector of deep cyclone (C2C), (c) upper sector of deep anticyclone (A2A).

Taking everything into account, anticyclonic influence in the cold season is enhanced, supporting the formation of Bora in the north and Sirocco along the Adriatic coast. Furthermore, DJF cyclonic Bora days (upper sector of cyclones) are decreasing and are replaced with cyclonic Sirocco events (front sector of cyclones). This is in agreement with studies suggesting that cyclone paths are moving northward $[19,20,43]$ and a decrease in the number of winter cyclones $[21,23]$. In the summer, Sirocco anticyclonic days, generated by the upper sector of anticyclones (A2), are replaced by Bora anticyclonic days, generated by the front part of anticyclones (A1). Moreover, the quasi-non-gradient flow from the northeastern quadrant decreases at the expense of anticyclonic days. Therefore, the anticyclonic influence strengthens in summer over the Adriatic.

\section{Conclusions}

The development of a novel semi-objective weather-type classification and its application to Bora and Sirocco projections was presented. We adjusted the preceding and widely used classification developed by Poje [1] for the Adriatic region. An ensemble of nine high resolution RCM simulations was employed for two 30-year periods: nearpresent day and future climate conditions under the RCP8.5 scenario. MSLP data and the height of the $500 \mathrm{hPa}$ level were examined, and one of $17 \mathrm{WTs}$ was associated with each simulated day. Furthermore, near-surface wind data were assessed for each day, and the Bora and Sirocco distributions were presented for the individual WT. The conclusions are the following:

- The ensemble of nine RCM simulations revealed a decrease in cyclonic activity over the Adriatic in the cold part of the year, accompanied by an increase in anticyclonic activity.

- The physics behind the WT definition is based on the fact that the development of severe Bora and Sirocco along the Adriatic is critically dependent on the synoptic setting to create an optimal set of mesoscale conditions. Therefore, WTs responsible for Bora and Sirocco generation are as expected, indicating the applicability of the classification. Bora wind over the northern Adriatic is very often accompanied by strong Sirocco wind over the southern Adriatic. C2 cyclones, during which the majority of Bora and Sirocco are generated in the near-present day, are usually deep Genoa cyclones with trajectories over the middle and southern Adriatic or cyclones from the western Mediterranean Sea. Anticyclonic Bora is generated mostly under the influence of the front sector (A1) and lower sector (A4), whereas anticyclonic Sirocco is mostly generated under the influence of the upper sector (A2). 
- The examination of climate projections discloses that in the DJF, the number of cyclonic Bora days (upper sector of cyclone, C2) decreases. The cyclonic (C2) Bora days are replaced by cyclonic Sirocco days (front sector of cyclones, C1). This suggests that cyclone paths are moving northward and that there is a decrease in the number of winter cyclones. Furthermore, the number of Sirocco anticyclonic days increases in DJF, generating weaker Sirocco events.

- In JJA, Sirocco anticyclonic days, generated by the upper sector of anticyclones (A2), are replaced by Bora anticyclonic days, generated by the front sector (A1) of anticyclones. The number of quasi-non-gradient northeasterly flow decreases at the expense of anticyclonic days.

Finally, the possibilities of applying these results to environmental and meteorological studies are wide and the presented classification can be implemented straightforwardly. Meteorological events, especially the extreme ones (e.g., dry spells, floods, extreme winds, snowstorms, etc.) affect human activities to a large extent and can be attributed to a particular weather type. Therefore, all mentioned extreme weather situations can be studied using the presented weather type classification.

Author Contributions: Conceptualization, A.B.V., M.T.P. and I.G.; methodology, A.B.V., M.T.P. and I.G.; software, A.B.V.; validation, A.B.V.; formal analysis, A.B.V.; investigation, A.B.V., M.T.P. and I.G.; resources, M.T.P. and I.G.; data curation, A.B.V.; writing-original draft preparation, A.B.V.; writing-review and editing, A.B.V., M.T.P. and I.G.; visualization, A.B.V.; supervision, M.T.P. and I.G.; project administration, M.T.P.; funding acquisition, M.T.P. All authors have read and agreed to the published version of the manuscript.

Funding: This research and APC was funded by SWALDRIC (IZHRZO-180587), which is financed within the Croatian-Swiss Research Program of the Croatian Science Foundation and the Swiss National Science Foundation, with funds obtained from the Swiss-Croatian Cooperation Programme. ABV wants to thank the L'Oreal-UNESCO scholarship programme "For Women in Science" for co-funding this research.

Data Availability Statement: Data supporting reported results can be found online at: https:/ esgfdata.dkrz.de/search/cordex-dkrz/ (accessed on 4 March 2018) and https:/ / repozitorij.meteo.hr/ (accessed on 16 April 2018).

Acknowledgments: We are grateful to the EURO-CORDEX modelling groups that performed the simulations and made their data available. We acknowledge the World Climate Research Programme's Working Group on Coupled Modelling, which is responsible for CMIP, and we thank the climate modelling groups for producing and making their model output available. RegCM4 simulations analyzed in this study were performed as a part of the Croatian Ministry of Environment and Energy project "Strengthening the Capacity of the Ministry of Environment and Energy for Climate Change Adaptation and development of the Draft Strategy for Climate Change Adaptation (Contract number: TF/HR/P3-M1-O1-010)" funded by the EU Transition Facility. This research was also enabled by SWALDRIC (IZHRZO-180587) project, which is financed within the Croatian-Swiss Research Program of the Croatian Science Foundation and the Swiss National Science Foundation, with funds obtained from the Swiss-Croatian Cooperation Programme.

Conflicts of Interest: The authors declare no conflict of interest.

\section{References}

1. Poje, D. Glavni Tipovi Vremena u Jugoslaviji i Njihova Zavisnost o Visinskim Strujanjima. Ph.D. Thesis, Faculty of Science, University of Zagreb, Zagreb, Croatia, 1965.

2. Lamb, H.H. Types and spells of weather around the year in the British Isles. Q. J. R. Meteorol. Soc. 1950, 76, 393-438. [CrossRef]

3. Yarnal, B.; Comrie, A.C.; Frakes, B.; Brown, D.P. Developments and prospects in synoptic climatology. Review. Int. J. Climatol. 2001, 21, 1923-1950. [CrossRef]

4. Philipp, A.; Bartholy, J.; Beck, C.; Erpicum, M.; Esteban, P.; Fettweis, X.; Huth, R.; James, P.; Jourdain, S.; Kreienkamp, F.; et al. COST 733CAT-A database of weather and circulation type classifications. Phys. Chem. Earth 2010, 35, 360-373. [CrossRef]

5. Huth, R.; Beck, C.; Philipp, A.; Demuzere, M.; Untstrul, Z.; Cahynova, M.; Kysely, J.; Tveito, O.E. Classification of atmospheric circulation patterns: Recent advances and applications. Ann. N. Y. Acad. Sci. 2008, 1146, 105-152. [CrossRef] [PubMed] 
6. Brinkmann, W.A.R. Modification of a correlation-based circulation pattern classification to reduce within-type variability of temperature and precipitation. Int. J. Climatol. 2000, 20, 839-852. [CrossRef]

7. Jones, P.D.; Kelly, P.M. Principal component analysis of the Lamb catalogue of Daily Weather-Types: Part 1, annual frequencies. J. Climatol. 1982, 2, 147-157. [CrossRef]

8. Riedinger, U.; Gratzki, A. Future weather types and their influence on mean and extreme climate indices for precipitation and temperature in Central Europe. Meteorol. Z. 2014, 23, 231-252. [CrossRef]

9. Jacob, D.; Teichmann, C.; Sobolowski, S.; Katragkou, E.; Anders, I.; Belda, M.; Benestad, R.; Boberg, F.; Buonomo, E.; Cardoso, R.M.; et al. Regional climate downscaling over Europe: Perspectives from the EURO-CORDEX community. Reg. Environ. Chang. 2020, 20. [CrossRef]

10. Bissolli, P.; Dittmann, E. The objective weather type classification of the German Weather Service and its possibilities of application to environmental and meteorological investigations. Meteorol. Z. 2001, 10, 253-260. [CrossRef]

11. Jelić, D.; Megyeri, O.A.; Malečić, B.; Belušić Vozila, A.; Strelec Mahović, N.; Telišman Prtenjak, M. Hail climatology along the northeastern Adriatic. J. Geophys. Res. Atmos. 2020, 125, e2020JD032749. [CrossRef]

12. Jelić, D.; Telišman Prtenjak, M.; Malečić, B.; Belušić Vozila, A.; Megyeri, O.A.; Renko, T. A New Approach for the Analysis of Deep Convective Events: Thunderstorm Intensity Index. Atmosphere 2021, 12, 908. [CrossRef]

13. Hueging, H.; Haas, R.; Born, K.; Jacob, D.; Pinto, J.G. Regional changes in wind energy potential over Europe using regional climate model ensemble projections. J. Appl. Meteorol. Climatol. 2012, 52, 903-917. [CrossRef]

14. Cardoso, R.M.; Soares, P.M.M.; Lima, D.C.A.; Semedo, A. The impact of climate change on the Iberian low-level wind jet: EURO-CORDEX regional climate simulation. Tellus A 2016, 68, 1-15. [CrossRef]

15. Räisänen, P.; Barker, H.W.; Khairoutdinov, M.F.; Li, J.; Randall, D.A. Stochastic generation of subgrid-scale cloudy columns for large-scale models. Q. J. R. Meteorol. Soc. 2004, 130, 2047-2067. [CrossRef]

16. Laprise, R.; de Elía, R.; Caya, D.; Biner, S.; Lucas-Picher, P.; Diaconescu, E.; Leduc, M.; Alexandru, A.; Separovic, L. Challenging some tenets of Regional Climate Modelling. Meteorol. Atmos. Phys. 2008, 100, 3-22. [CrossRef]

17. Kjellström, E.; Nikulin, G.; Hansson, U.; Strandberg, G.; Ullerstig, A. 21st century changes in the European climate: Uncertainties derived from an ensemble of regional climate model simulations. Tellus A 2011, 63, 24-40. [CrossRef]

18. Reyers, M.; Moemken, J.; Pinto, J.G. Future changes of wind energy potentials over Europe in a large CMIP5 multi-model ensemble. Int. J. Climatol. 2016, 36, 783-796. [CrossRef]

19. $\mathrm{Hu}, \mathrm{Z} . \mathrm{Z}$; $\mathrm{Wu}, \mathrm{Z}$. The intensification and shift of the annual North Atlantic Oscillation in a global warming scenario simulation. Tellus A 2004, 56, 112-124. [CrossRef]

20. Knippertz, P.; Ulbrich, U.; Speth, P. Changing cyclones and surface wind speeds over the North Atlantic and Europe in a transient GHG experiment. Clim. Res. 2000, 15, 109-122. [CrossRef]

21. McCabe, G.J.; Clark, M.P.; Serreze, M.C. Trends in northern hemisphere surface cyclone frequency and intensity. J. Clim. 2001, 14, 2763-2768. [CrossRef]

22. Catto, J.L.; Ackerley, D.; Booth, J.F.; Champion, A.J.; Colle, B.A.; Pfahl, S.; Pinto, J.G.; Quinting, J.F.; Seiler, C. The Future of Midlatitude Cyclones. Curr. Clim. Chang. Rep. 2019, 5, 407-420. [CrossRef]

23. Nissen, K.M.; Leckebusch, G.C.; Pinto, J.G.; Renggli, D.; Ulbrich, S.; Ulbrich, U. Cyclones causing wind storms in the Mediterranean: Characteristics, trends and links to large-scale patterns. Nat. Hazard Earth Sys. Sci. 2010, 10, 1379-1391. [CrossRef]

24. Pinto, J.; Karremann, M.; Born, K.; Della-Marta, P.; Klawa, M. Loss potentials associated with European windstorms under future climate conditions. Clim. Res. 2012, 54, 1-20. [CrossRef]

25. Zappa, G.; Shaffrey, L.C.; Hodges, K.I. The Ability of CMIP5 Models to Simulate North Atlantic Extratropical Cyclones. J. Clim. 2013, 26, 5379-5396. [CrossRef]

26. Pandžić, K.; Likso, T. Eastern Adriatic typical wind field patterns and large-scale atmospheric conditions. Int. J. Climatol. 2005, 25, 81-98. [CrossRef]

27. Belušić, A.; Telišman Prtenjak, M.; Güttler, I.; Ban, N.; Leutwyler, D.; Schär, C. Near-surface wind variability over the broader Adriatic region: Insights from an ensemble of regional climate models. Clim. Dyn. 2018, 50, 4455-4480. [CrossRef]

28. Belušić Vozila, A.; Güttler, I.; Ahrens, B.; Obermann-Hellhund, A.; Telišman Prtenjak, M. Wind over the Adriatic Region in CORDEX Climate Change Scenarios. J. Geophys. Res. Atmos. 2019, 124, 110-130. [CrossRef]

29. Grisogono, B.; Belušić, D. A review of recent advances in understanding the meso- and microscale properties of the severe Bora wind. Tellus A 2009, 61, 1-16. [CrossRef]

30. Samuelsson, P.; Jones, C.G.; Willén, U.; Ullerstig, A.; Gollvik, S.; Hansson, U.; Jansson, E.; Kjellström, C.; Nikulin, G.; Wyser, K.; et al. The Rossby Centre Regional Climate model RCA3: Model description and performance. Tellus A 2011, 63, 4-23. [CrossRef]

31. Giorgi, F.; Coppola, E.; Solmon, F.; Mariotti, L.; Sylla, M.; Bi, X.; Elguindi, N.; Diro, G.T.; Nair, V.; Giuliani, G.; et al. RegCM4: Model description and preliminary tests over multiple CORDEX domains. Clim. Res. 2012, 936, 577X. [CrossRef]

32. Moss, R.; Edmonds, J.; Hibbard, K.A.; Manning, M.R.; Rose, S.K.; van Vuuren, D.P.; Carter, T.R.; Emori, S.; Kainuma, M.; Kram, T.; et al. The next generation of scenarios for climate change research and assessment. Nature 2010, 463, 747-756. [CrossRef]

33. Voldoire, A.; Sanchez-Gomez, E.; Mélia, D.S.Y.; Decharme, B.; Cassou, C.; Sénési, S.; Valcke, S.; Beau, I.; Alias, A.; Chevallier, M.; et al. The CNRM-CM5.1 global climate model: Description and basic evaluation. Clim. Dyn. 2013, 40, 2091-2121. [CrossRef] 
34. Hazeleger, W.; Wang, X.; Severijns, C.; Ştefănescu, S.; Bintanja, R.; Sterl, A.; Wyser, K.; Semmler, T.; Yang, S.; van den Hurk, B.; et al. EC-Earth V2.2: Description and validation of a new seamless Earth system prediction model. Clim. Dyn. 2012, 39, $2611-2629$. [CrossRef]

35. Dufresne, J.-L.; Foujols, M.-A.; Denvil, S.; Caubel, A.; Marti, O.; Aumont, O.; Balkanski, Y.; Bekki, S.; Bellenger, H.; Benshila, R.; et al. Climate change projections using the IPSL-CM5 Earth System Model: From CMIP3 to CMIP5. Clim. Dyn. 2013, 40, 2123-2165. [CrossRef]

36. Martin, G.M.; Bellouin, N.; Collins, W.J.; Culverwell, I.D.; Halloran, P.R.; Hardiman, S.C.; Hinton, T.J.; Jones, C.D.; McDonald, R.E.; McLaren, A.J.; et al. The HadGEM2 family of Met Office Unified Model climate configurations. Geosci. Model Dev. 2011, 4, 723-757. [CrossRef]

37. Giorgetta, M.A.; Jungclaus, J.; Reick, C.H.; Legutke, S.; Bader, J.; Böttinger, M.; Brovkin, V.; Crueger, T.; Esch, M.; Fieg, K.; et al. Climate and carbon cycle changes from 1850 to 2100 in MPI-ESM simulations for the Coupled Model Intercomparison Project phase 5. J. Adv. Model Earth Syst. 2013, 5, 572-597. [CrossRef]

38. Van Bebber, W.J. Die Zugstrassen der barometrischen Minima nach den Bahnenkarten der Deutschen Seewarte fur den Zeitraum 1875-1890. Meteorl. Z. 1891, 8, 361-366.

39. Sfîcă, L.; Croitoru, A.E.; Iordache, I.; Ciupertea, A.F. Synoptic Conditions Generating Heat Waves and Warm Spells in Romania. Atmosphere 2017, 8, 50. [CrossRef]

40. Poje, D. Bura (Bora) and burin at Split. Hrvat. Meteorološki Časopis 1995, 30, 1-19.

41. Međugorac, I.; Pasarić, M.; Orlić, M. Severe flooding along the eastern Adriatic coast: The case of 1 December 2008. Ocean Dyn. 2015, 65, 817-830. [CrossRef]

42. Međugorac, I.; Pasarić, M.; Güttler, I. Will the wind associated with the Adriatic storm surges change in future climate? Theor. Appl. Climatol. 2020, 143, 1-18. [CrossRef]

43. Bengtsson, L.; Hodges, K.I.; Keenlyside, N. Will Extratropical Storms Intensify in a Warmer Climate? J. Clim. 2009, 22, $2276-2301$. [CrossRef]

44. Huth, R.; Kyselý, J.; Pokorna, L. A GCM Simulation of Heat Waves, Dry Spells, and Their Relationships to Circulation. Clim. Chang. 2000, 46, 29-60. [CrossRef]

45. Vial, J.; Osborn, T.J.; Lott, F. Sudden stratospheric warmings and tropospheric blockings in a multi-century simulation of the IPSL-CM5A coupled climate model. Clim. Dyn. 2013, 40, 2401-2414. [CrossRef]

46. Nabizadeh, E.; Hassanzadeh, P.; Yang, D.; Barnes, E.A. Size of the atmospheric blocking events: Scaling law and response to climate change. Geophys. Res. Lett. 2019, 46, 13488-13499. [CrossRef]

47. Horvath, K.; Ivatek-Šahdan, S.; Ivančan-Picek, B.; Grubišić, V. Evolution and Structure of Two Severe Cyclonic Bora Events: Contrast between the Northern and Southern Adriatic. Weather Forecast. 2009, 24, 946-964. [CrossRef]

48. Telišman Prtenjak, M.; Viher, M.; Jurković, J. Sea/land breeze development during a summer bora event along the north-eastern Adriatic coast. Q. J. R. Meteorol. Soc. 2010, 136, 1554-1571. [CrossRef]

49. Horvath, K.; Lin, Y.L.; Ivančan-Picek, B. Classification of Cyclone Tracks over the Apennines and the Adriatic Sea. Mon. Wea. Rev. 2008, 136, 2210-2227. [CrossRef]

50. Penzar, B.; Penzar, I.; Orlić, M. Vrijeme i Klima Hrvatskog Jadrana; Hydrographic Institute Croatia: Zagreb, Croatia, 2001 ; p. 258.

51. Branković, Č. Stanje Atmosfere za Vrijeme Juga na Jadranu. Master's Thesis, Faculty of Science, University of Zagreb, Zagreb, Croatia, 1974.

52. Snyder, M.A.; Sloan, L.C.; Diffenbaugh, N.S.; Bell, J.L. Future climate change and upwelling in the California Current. Geophys. Res. Lett. 2003, 30, 1823. [CrossRef]

53. Horvath, K.; Ivančan-Picek, B. A numerical analysis of a deep Mediterranean lee cyclone: Sensitivity to mesoscale potential vorticity anomalies. Meteorol. Atmos. Phys. 2009, 103, 161-171. [CrossRef] 